\title{
In vitro Anthelmintic Efficacy of Medicinal Plants against Heterakis gallinarum in Village Chickens
}

\author{
Marizvikuru Mwale ${ }^{1} \&$ Patrick J. Masika ${ }^{2}$ \\ ${ }^{1}$ Institute for Rural Development, University of Venda, Thohoyandou, South Africa \\ ${ }^{2}$ Agricultural and Rural Development Research Institute (ARDRI), University of Fort Hare, Alice, South Africa \\ Correspondence: Marizvikuru Mwale, Institute for Rural Development, University of Venda, Thohoyandou, \\ South Africa. Tel: 27-15-962-8809. E-mail: marizvikuru.manjoro@univen.ac.za
}

Received: August 27, 2015 Accepted: October 6, 2015 Online Published: November 15, 2015

doi:10.5539/jas.v7n12p247 URL: http://dx.doi.org/10.5539/jas.v7n12p247

\begin{abstract}
Heterakis gallinarum impedes the productivity of village chickens and hence their socio-economic contribution to rural communties. Smallholder farmers are endowed with vast indigenous knowledge for controlling $H$. gallinarum and they predominantly use Aloe ferox, Agave sisalana and Gunnera perpensa. However, their anthelminthic efficacy is unknown. Therefore, our objective was to determine the in vitro anthelmintic efficacy of A. ferox, A. sisalana and G. perpensa against H. gallinarum. Heterakis gallinarum worms were recovered from caeca of 20 village chickens. Ten worms were randomly introduced in each of the 42 petri-dishes. Treatments were positive control (distilled water), negative control (mebendazole) and A. ferox, A. sisalana and G. perpensa aqueous extracts at dosage of 7.25, 14.5, 29 and $58 \mathrm{mg} / \mathrm{mL}$. The procedure was done in triplicate. Worm motility and mortality indices were calculated. Among plant, A. sisalana $(14.5 \mathrm{mg} / \mathrm{mL})$ had the greatest $(80 \%)$ worm motility inhibition at $12-\mathrm{h}$ interval $(\mathrm{p}<0.05)$ and the greatest worm mortality index $(80 \%)$ showing that the plant has anthelmintic properties. Seventy percent of worms were recovered after $48 \mathrm{~h}$ following treatment with A. ferox $(58 \mathrm{mg} / \mathrm{mL})$. Agave sisalana $(14.5 \mathrm{mg} / \mathrm{mL})$ was the most efficient plant in reducing motility and causing mortality of $H$. gallinarum in vitro. Findings are useful to resource-constrained farmers who use crude extracts, to select the best plant and to pharmaceutical companies for manufacturing anthelmintic drugs.
\end{abstract}

Keywords: gastro-intestinal parasites, plant leaf extracts, poultry, worm mortality, worm motility

\section{Introduction}

Village chickens contribute significantly to rural communities' population in Africa (Blackie, 2014). According to Blackie (2014), village chickens contribute towards animal protein mainly through eggs and meat, and household income. They are also a crucial species for redressing gender imbalance in mainstreaming of livestock production (Guèye, 2000). In addition, village chickens are essential for socio-cultural purposes such as payment of lobola (pride price or bridewealth) which is a significant element of marriage in some Southern African cultures (Ansell, 2001), appeasement, greeting visitors and gifts for strengthening social cohesion. In some cases when paying the pride price chickens are brought by the bridegroom and used as relish during the event. Village chickens are easy to manage and in most cases, in Africa, they are managed by women and children who are the majority in the rural areas (Mahlako, 1996; Sonaiya, 2005; Moreki, 2010). The chickens can also be easily reared as a sideline enterprise together with other farming enterprises. It is therefore pertinent to improve village chicken productivity and to enhance their importance especially on household protein security and annul net income.

Despite their immense contribution to rural livelihoods, Phiri et al. (2007) asserted that village chickens are adversely affected by gastro-intestinal (GI) parasites. Heterakis gallinarum is among the prevalent GI parasites infesting village chickens (Abdelqader, Gauly, Wollny, \& Abo-hehada, 2008). This is because most rural places are located in marginal areas where environmental conditions are conducive for the perpetuation of $H$. gallinarum. Besides, the chickens are vulnerable to parasites due to their scavenging feeding habit. This exposes them to parasite infection and re-infection. Smallholder farmers are left with no choice except to battle with the challenge. This is, however, a huge challenge considering that the majority of smallholder farmers in the rural sector are resource-constrained. Furthermore, conventional medicines such as albendazole for controlling GI 
parasites are expensive and have their own demerits. These include drug resistance by the parasite, residual effects in animal products, lack of knowledge on the use of drugs and exorbitant prices (Kaplan, 2004; Coles et al., 2006).

The drawbacks of conventional medicines create an opportunity for rural communities to divert to and predominantly use medicinal plants (Masimba, Mbiriri, Kashangura, \& Mutibvu, 2011; Moreki, 2012). This is apt as the smallholder farmers are endowed with invaluable indigenous knowledge for controlling GI parasites in livestock (Moreki, 2012). As such, medicinal plants such as Aloe ferox, Agave sisalana and Gunnera perpensa are used by the rural communities in the Eastern Cape province of South Africa to control GI parasites in village chickens, especially H. gallinarum (Mwale \& Masika, 2009). The communities believe that plants are effective and have no side effects. Therefore, the current study was conducted to determine the in vitro anthelminthic efficacy of these plants against $H$. gallinarum.

\section{Materials and Methods}

\subsection{Study Site}

The in vitro study was conducted at the Agricultural and Rural Development Research Institute (ARDRI) at the University of Fort Hare, Alice, South Africa.

\subsection{Collection of Plant Material}

Fresh leaves of A. ferox, A. sisalana and G. perpensa were collected from Centane district $\left(32^{\circ} 38^{\prime} 63^{\prime \prime} \mathrm{S}\right.$ and $28^{\circ} 24^{\prime} 36^{\prime \prime} \mathrm{E}$; elevation $50 \mathrm{~m}$ ) in the Eastern Cape Province of South Africa in October 2007. The plant materials were identified at Selmar Schonland Herbarium at Botany Department, Rhodes University, in South Africa. Voucher specimens (MMAN 2007/01), (MMAN 2007/02) and (MMAN 2007/03) for A. ferox, A. sisalana and G. perpensa, respectively were deposited in the Giffen Herbarium at the University of Fort Hare for reference purposes and future research.

\subsection{Preparation of Plant Extracts}

The collected leaves were washed using cold water to remove dirt. Spines around the leaves of $A$. ferox and $A$. sisalana were removed using a knife. The leaves from the three medicinal plants were sliced before blending. Two hundred grams of each of the sliced A. ferox, A. sisalana and G. perpensa leaves were mixed with 100, 200 and $400 \mathrm{~mL}$ of distilled water, respectively. The mixture for each plant material was blended using an electric blender for 3 minutes to obtain 200, 100 and 50\% (w/v) extract for A. ferox, A. sisalana and G. perpensa, respectively (Githiori, Höglund, Waller, \& Baker, 2003). The blended material was squeezed through a muslin cloth. The extract from the three plants, was freeze-dried at $-50{ }^{\circ} \mathrm{C}$ under vacuum using a lyophilizer (model Savant RVT 4104, Thermo Fisher Scientific, Inc., Waltham, MA, USA) and kept in a freezer at $-20{ }^{\circ} \mathrm{C}$ until use. The extracts were later reconstituted into $7.25,14.5,29$ and $58 \mathrm{mg} / \mathrm{mL}$.

\subsection{Animals}

A total of 20 mature village chickens of either sex, aged between 6 and 12 months, were acquired from farmers at Zixenene village in Amatola basin ( $32^{\circ} 42^{\prime} 89^{\prime \prime} \mathrm{S}$ and $27^{\circ} 02^{\prime} 36^{\prime \prime} \mathrm{E}$; elevation $\left.541 \mathrm{~m}\right)$. The average live weight of the chickens was $1.36 \pm 0.667 \mathrm{~kg}$. The University of Fort Hare ethics committee and the ethical standards declared by Helsinki in 1964 (World Medical Organization, 1996) were followed.

\subsection{In vitro Evaluations and Measurements}

Gastro-intestinal worms were quickly recovered from the gut of sacrificed chickens. Only $H$. gallinarum worm species was recovered from the caeca. Distilled water was used as the negative control and mebendazole (Vermox ${ }^{\circledR}$ SD suspension $50 \mathrm{mg} / \mathrm{mL}$, Janssen-Cilag Pharmaceutica Ltd, Sandton, Gauteng, South Africa) as the positive control. A mL of either distilled water, mebendazole or plant extracts of doses 7.25, 14.5, 29 and 58 $\mathrm{mg} / \mathrm{mL}$ (an equivalent of 50,100, 200 and $400 \mathrm{mg} / \mathrm{kg}$ doses, respectively) was added into petri-dishes using a 1 $\mathrm{mL}$ syringe.

Four milliliters of Ringer's lactate solution, for the nourishment of the worms, were added into these petri-dishes after which 10 worms were randomly introduced in each petri-dish. The procedure was conducted in triplicate. Inhibition of worm motility was observed for 6 seconds at hourly interval for 6 hours, then after every 12 hours for 36 hours. The number of immotile worms was recorded per treatment, during the observation period, and worm motility index was calculated using the formula described by Hounzangbe-Adote, Fouraste, Moutairou, and Hoste (2005), as shown:

$$
\text { Motility index }=\frac{\text { Number of immotile worms }}{\text { Total number of worms }} \times 100
$$


After 36 hours, all worms were washed and lactate Ringer's solution was added. The worms were then observed for recovery after leaving the treatments to stand for $30 \mathrm{~min}$. The number of worms that recovered and those that failed to recover were recorded, after which a mortality index was calculated as follows according to Eguale, Tilahun, Debella, Feleke, and Makonnen (2007):

\subsection{Data Analyses}

$$
\text { Motility index }=\frac{\text { Number of dead or paralysed worms }}{\text { Total number of worms initially put in petri-dish }} \times 100
$$

Data were tested for normality using the UNIVARIATE procedure of SAS (SAS Institute Inc., Cary, NC, USA). The square root transformed data to confer normality was analysed using the general linear model (GLM) procedure of SAS to test the effect of medicinal plant materials on H. gallinarum worm motility and mortality.

\section{Results}

There was no inhibition of worm motility $(\mathrm{p}>0.05)$ during the first hour of observation. In the second and third hour, there was inhibition of worm motility but it was not different between the treatments $(p>0.05)$. From the $4^{\text {th }}$ hour to the end of the observation period, significant differences in the inhibition of worm motility were observed; A. sisalana extract $(14.5 \mathrm{mg} / \mathrm{mL})$ had the greatest $(80 \%)$ worm motility inhibition at $12-\mathrm{h}$ interval $(\mathrm{p}<$ $0.05)$. There were significant differences in the efficacy of the anthelmintic effect of the tested medicinal plants and there was an interaction between treatments used and time of observation $(\mathrm{p}<0.05)$. A significantly high number $(70 \%)$ of worms were recovered after $48 \mathrm{~h}$ following treatment with $A$. ferox $(58 \mathrm{mg} / \mathrm{mL})$ while 20 and $0 \%$ worms were recovered from $A$. sisalana and mebendazole treatments, respectively. Aloe ferox scarcely inhibited worm motility and/or caused worm mortality. Gunnera perpensa generally had 50\% recovery for all the dose levels and distilled water had $67 \%$. As shown in Table 1, among plants, A. sisalana extract (14.5 $\mathrm{mg} / \mathrm{mL}$ ) had the greatest worm mortality index.

Table 1. Mortality index $( \pm \mathrm{SE})$ for worms treated with $A$. ferox, A. sisalana and $G$. perpensa

\begin{tabular}{|c|c|c|c|c|c|}
\hline \multirow{3}{*}{ Test material } & & \multicolumn{4}{|c|}{ Mortality index (\%) } \\
\hline & & \multicolumn{4}{|c|}{ Dose $(\mathrm{mg} / \mathrm{mL})$} \\
\hline & & 7.25 & 14.5 & 29 & 58 \\
\hline A. ferox & & $53^{\text {cd }}$ & $50^{\text {cde }}$ & $40^{\mathrm{def}}$ & $30^{f}$ \\
\hline A. sisalana & & $60^{\mathrm{c}}$ & $80^{\mathrm{b}}$ & $60^{c}$ & $60^{\mathrm{c}}$ \\
\hline G. perpensa & & $50^{\text {cde }}$ & $53^{\mathrm{cd}}$ & $60^{\mathrm{c}}$ & $50^{\text {cde }}$ \\
\hline Distilled water & $33^{\mathrm{ef}}$ & & & & \\
\hline Mebendazole $(50 \mathrm{mg} / \mathrm{ml})$ & $100^{\mathrm{a}}$ & & & & \\
\hline Standard error & & & 0.435 & & \\
\hline
\end{tabular}

\section{Discussion}

The findings indicate that in the first hour of the experiment the $H$. gallinarum worms were still capable of withstanding the effect of the commercial anthelmintic and the aqueous leaf extracts of medicinal plants. During the second and third hour, motility findings show that $H$. gallinarum worms succumbed to the anti-parasitic effects. Inhibition of worm motility is a crucial process for mortality of worms and hence anthelmintic property of a medicinal plant or anthelmintic drug, thereby relieving the animal from parasite infections (Hoque, Mostofa, Awal, Choudhury, Hossain, \& Alam, 2006). The ability of A. sisalana extract $(14.5 \mathrm{mg} / \mathrm{mL})$ to exert high worm inhibition motility at 12-h interval shows that the plant has some anthelmintic properties. The mortality index was close to that of mebendazole proving that although not statistically different, the plant has anthelmintic properties. This is in agreement with Hoque et al. (2006) who reported decrease in ascariasis parasites due to oral administration of pineapple leaf extracts to indigenous chickens. This entails that medicinal plants can effectively reduce worm burden in village chickens.

Active anthelmintic compounds reported to be present in medicinal plants include anthraquinones, alkaloids, aloe-emodine, cucurbitin, sulphuric compounds and naphtoquinone substances (Guarrera, 1999; Adedapo et al., 2008). Characterisation of chemical components in the aqueous extract of $A$. sisalana is, therefore, important. This is crucial in ameliorating the increasingly growing challenge of parasite resistance and unavailability of 
anthelmintic drugs to resource-limited farmers (Coles et al., 2006; Hussain, Khan, Iqbal, \& Sajid, 2008). In the current study, A. ferox and G. perpensa provided minimum inhibition of H. gallinarum motility and mortality, indicating that anthelmintic compounds in these plants could possibly be insufficient enough to immobilize or kill the worms. It is imperative to determine the anthelmintic efficacy of these plants against $\mathrm{H}$. gallinarum using other in vitro methods and in vivo methods to ascertain if the anthelmintic properties could be exhibited. However, the findings indicate that $G$. perpensa at $29 \mathrm{mg} / \mathrm{mL}$ dose demonstrated anthelmintic properties. Nonetheless, the compounds responsible for the anthelmintic property of G. perpensa are not known. It is worthwhile to evaluate the chemical compounds that are responsible for the anthelmintic activities of $G$. perpensa.

The current findings indicate that $A$. ferox has little anthelmintic activity as the plant had the greatest number of H. gallinarum worms recovered in the worm recovery procedure at the end of the experiment. This signifies that A. ferox scarcely inhibits worm motility and/or causes worm mortality. Steenkamp and Stewart (2007), however, reported that $A$. ferox has been used as an anthelmintic. The anthelmintic activities of $A$. ferox could, therefore, be ascribed to the purgative and/or laxative effects of A. ferox (Blumenthal, 1998, cited by Steenkamp and Stewart, 2007). It is, therefore, imperative to characterize the anthelmintic compounds of $A$. ferox, to ascertain the in vivo anthelmintic efficacy of the plant and determine the mechanism of action of the plant's anthelmintic compounds.

\section{Conclusion}

Aloe ferox, Agave sisalana and Gunnera perpensa have anthelmintic properties. Agave sisalana at a dosage of $14.5 \mathrm{mg} / \mathrm{mL}$ dose was the most efficacious in reducing motility and causing mortality of $H$. gallinarum. This entails that medicinal plants can effectively reduce worm burden in village chickens thereby enhancing the productivity of chickens and ultimately improve rural livelihoods. Resource-constrained farmers may thus use these plants at recommended dose levels in controlling GI parasites in village chickens, especially A. sisalana $(14.5 \mathrm{mg} / \mathrm{mL}$ dose). It is imperative to evaluate the efficacy of these plants in vivo, so as to be well informed on the anthelmintic properties of these plants. Moreover, it is worthy determining the medicinal plants compounds responsible for the anthelmintic properties and their mechanism of action.

\section{References}

Abdelqader, J. A., Gauly, M., Wollny, C. B. A., \& Abo-Shehada M. N. (2008). Prevalence and burden of gastrointestinal helminthes among local chickens, in northern Jordan. Preventive Veterinary Medicine, 85, 17-22. http://dx.doi.org/10.1016/j.prevetmed.2008.01.009

Adedapo, A. A., Sofidiya, M. O., Maphosa, V., Moyo, B., Masika, P. J., \& Afolayan, A. J. (2008). Anti-inflammatory and anti-nociceptive activities of the aqueous extract of Cussonia paniculata stem Bark. Records of Natural Products, 2(2), 46-53.

Ansell, N. (2001). 'Because it's Our Culture!' (Re)negotiating the Meaning of Lobola in Southern African Secondary Schools. Journal of Southern African Studies, 27(4), 697-716. http://dx.doi.org/10.1080/03057070120090691

Blackie, S. (2014). Contribution of Village Chickens to Animal Protein Consumption and Income of Rural Households in the Greater Accra Region, Ghana. Developing Country Studies, 4(10), 43-48.

Coles, G. C., Jackson, F., Pomroy, W. E., Prichard, R. K., von Samson-Himmelstjerna, G., Silvestre, A., ... Vercruysse, J. (2006). The detection of anthelmintic resistance in nematodes of veterinary importance. Veterinary Parasitology, 136, 167-185. http://dx.doi.org/10.1016/j.vetpar.2005.11.019/j.jep.2006.10.003

Eguale, T., Tilahun, G., Debella, A., Feleke, A., \& Makonnen, E. (2007). In vitro and in vivo anthelmintic activity of crude extracts of Coriandrum sativum against Haemonchus contortus. Journal of Ethnopharmacology, 110, 428-433. http://dx.doi.org/10.1016/j.jep.2006.10.003

Githiori, J. B., Höglund, J., Waller, P. J., \& Baker, L. (2003). Evaluation of anthelmintic properties of extracts from some plants used as livestock dewormers by pastoralist and smallholder farmers in Kenya against Heligmosomoidespolygyrus infections in mice. Veterinary Parasitology, 118, 215-226. http://dx.doi.org/10.1016/j.vetpar.2003.10.006

Guarrera, P. M. (1999). Traditional anthelmintic, antiparasitic and repellent uses of plants in Central Italy. Journal of Ethnopharmacology, 68(1-3), 183-192. http://dx.doi.org/10.1016/S0378-8741(99)00089-6

Guèye, E. F. (2000). The role of family poultry in poverty alleviation, food security and the promotion of gender

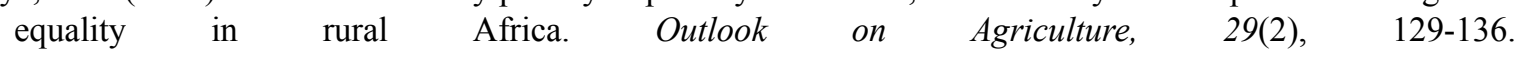


http://dx.doi.org/10.5367/000000000101293130

Hoque, M. E., Mostofa, M., Awal, M. A., Choudhury, M. E., Hossain, M. A., \& Alam, M. A. (2006). Comparative efficacy of Piperazine Citrate, Levamisole and Pineapple Leaves Extract against naturally infected ascariasis in Indigenous Chickens. Bangladesh Journal of Veterinary Medicine, 4(1), 27-29.

Hounzangbe-Adote, S., Fouraste, I., Moutairou, K., \& Hoste, H. (2005). In vitro effects of four tropical plants on the activity and development of the parasitic nematode, Trichostrongylus colubriformis. Journal of Helminthology, 79, 29-33. http://dx.doi.org/10.1079/JOH2004265

Hussain, A., Khan, M. N., Iqbal, Z., \& Sajid, M. S. (2008). An account of the botanical anthelmintics used in traditional veterinary practices in Sahiwal district of Punjab, Pakistan. Journal of Ethnopharmacology, 119, 185-190. http://dx.doi.org/10.1016/j.jep.2008.06.034

Mahlako, M. A. (1996). The Role of Women in Rural Development: The Case of the Molopo District of the North West Province (Master's thesis, University of Johannesburg, Gauteng, South Africa). Retrieved from https://ujdigispace.uj.ac.za/handle/10210/5756

Masimba, E. S., Mbiriri, D. T., Kashangura, M. T., \& Mutibvu, T. (2011). Indigenous practices for the control and treatment of ailments in Zimbabwe's village poultry. Livestock Research for Rural Development, 23(12). Retrieved from http://lrrd.cipav.org.co/lrrd23/12/masi23257.htm

Moreki, J. C. (2010). Village poultry production in Serowe-Palapye sub-district of Botswana. Livestock Research for Rural Development, 22(3). Retrieved from http://www.lrrd.cipav.org.co/lrrd22/3/more22046.htm

Moreki, J. C. (2012). Documentation of ethnoveterinary practices used in family poultry in Botswana. Veterinary World, 18-21.

Mwale, M., \& Masika, P. J. (2009). Ethno-veterinary control of parasites, management and role of village chickens in rural households of Centane district in the Eastern Cape, South Africa. Tropical Animal Health and Production, 41, 1685-1693. http://dx.doi.org/10.1007/s11250-009-9366-z

Phiri, I. K., Phiri, A. M., Ziela, M., Chota, A., Masuku, M., \& Monrad, J. (2007). Prevalence and distribution of gastrointestinal helminths and their effects on weight gain in free-range chickens in Central Zambia. Tropical Animal Health and Production, 39, 309-315. http://dx.doi.org/10.1007/s11250-007-9021-5

Sonaiya, F. ( 2005). Smallholder family poultry as a tool to initiate rural development. Poultry in the $21^{\text {st }}$ Century. Retrieved form http://www.fao.org/AG/againfo/home/ events/docs/part3/3_2.pdf

Steenkamp, V., \& Stewart, M. J. (2007). Medicinal Applications and Toxicological Activities of Aloe Products. Pharmaceutical Biology, 45, 411-420. http://dx.doi.org/10.1080/13880200701215307

World Medical Organization. (1996). Declaration of Helsinki. British Medical Journal, 313(7070), $1448-1449$. http://dx.doi.org/10.1136/bmj.313.7070.1448a

\section{Copyrights}

Copyright for this article is retained by the author(s), with first publication rights granted to the journal.

This is an open-access article distributed under the terms and conditions of the Creative Commons Attribution license (http://creativecommons.org/licenses/by/3.0/). 